\title{
THE MOBILE SERVICE OF AGRICULTURAL MACHINES AS THE ELEMENT OF THE SUPPORT FOR THE SUSTAINABLE AGRICULTURE
}

\author{
Sławomir JUŚCIŃSKI \\ Department of Power Engineering and Transportation, Faculty of Production Engineering, University of Life \\ Sciences in Lublin, POLAND \\ E-mail: slawomir.juscinski@up.lublin.pl
}

Key words: maintenance of agricultural vehicles and machines, servicing, sustainable agriculture

\begin{abstract}
The current article presents the problems of agricultural production, including the sustainable system of farming, related to servicing agricultural vehicles and machines. It discusses solutions which ensure support for sustainable development. Moreover, it presents research into maintenance of agricultural vehicles and machines conducted by an authorised service in the aspect of the distance between the site where the works are performed and the premises of the company. It also presents the structure of service orders for four radii measuring $r=0 \mathrm{~km}, 0 \mathrm{~km}$ $<r \leq 50 \mathrm{~km}, 50 \mathrm{~km}<r \leq 100 \mathrm{~km}$ and $r>100 \mathrm{~km}$. The study was conducted in the years 2003-2013 in an enterprise which offers authorised servicing. The structure of 17,402 service orders executed in the company's garage $(\mathrm{r}=0)$ and those executed on farms or under field conditions $(r>0)$ were represented graphically and analysed statistically with the use of the $\mathrm{R}$ programme.
\end{abstract}

\section{INTRODUCTION}

A sustainable system of farming which prevents the loss of organic matter in soil requires increased expenditures on agricultural activities. The promotion of such a method has been supported for years by subsidies from subsequent European Union programmes. Sustainable agriculture, introduced as part of the Rural Development Programme for the years 2007-2013, is continued as part of agricultural-environmental-climatic Package 1, which is in force in RDP for the years 2014-2020. An element which supports the rational use of natural resources and the limiting of the negative effect agriculture has on the environment is, to a significant extent, the up-to-date maintenance of agricultural vehicles and machines. Ensuring timely completion of agrotechnical works both influences the effectiveness of farming activities and optimises their effectiveness in the aspect of affecting the environment. However, a necessary condition is to possess technically fit agricultural vehicles and machines as well as the guarantee of restoring them to usefulness quickly by a service station.

Contemporary agricultural production, especially on larger farm areas, makes use of modern and efficient vehicles and machines produced by international concerns. The producers have built an up-to-date structure in Poland which distributes products and replacement parts as well as offers comprehensive maintenance services (Juściński 2012a, 2012b; Lorencowicz and Cupiał 2012, 2013; Tomczyk 2015). The distribution of users of vehicles and machines is uneven both across the country and particular voivodeships. Service orders are made by users living at various distances from dealerships. In order to reduce the costs of transporting brokendown agricultural vehicles and machines, as well as the time of repairing them, various forms of executing orders are employed (Buchwald and Staszak 2013, Rzeźnik et al. 2015, Skrobacki and Ekielski 2012). Maintenance services conducted in service stations constitute only a part of the demand for servicing, as an increasing number of orders is realised by mobile servicing teams in the field (Juściński 2012c, Niari et al., 2012). Maintenance services on modern vehicles and machines are performed in an area with a radius measuring at least several dozen kilometres. It creates difficulties in managing various works aimed at fixing operational failures or conducting repairs or inspections. A random configuration of types of works and their geographical location is a logistic challenge for the servicing department. Farmers' universal access to information and communication technologies provides support for maintenance services, as it facilitates making arrangements and reduces the time of waiting for repairs to be made (Cupiał and Kobuszewski 2011, Cupiał et al., 2015). It should be stressed that ensuring 
an optimal level of service, in face of varying demand, generates high fixed costs of the functioning of maintenance services (Gazzarin 2014, Gazzarin and Lips 2013). It is only possible for mechanics to travel to execute individual orders in the months when demand is low. One method to increase the rate of utilising time for effective work of servicing teams is to execute several orders on subsequent customers' premises during a single trip.

\section{MATERIAL AND METHODS}

The aim of the conducted market research was the identification and analysis of the demand for the maintenance of agricultural vehicles and machines realised by authorised services in the aspect of the distance between the place of performing works and the premises of the company. The study concerned four radii (distance): $r=0 \mathrm{~km}, 0 \mathrm{~km}<r \leq 50 \mathrm{~km}, 50 \mathrm{~km}<r \leq 100 \mathrm{~km}$ and $r>100 \mathrm{~km}$. Statistical analysis of inspections and repairs was conducted for $r=0 \mathrm{~km}$ and $r>$ $0 \mathrm{~km}$, or for services in the company's garage and all works in the field. The research conducted in the years 2003-2013 concerned servicing departments which offered maintenance services for agricultural vehicles and machines. Inspection and repair orders executed on the premises of service stations, on farms and under field conditions involved agricultural tractors produced by John Deere, Zetor, Pronar, Same, Deutz Fahr and Lamborghini. Maintenance services were also performed on agricultural machines produced by such concerns as John Deere, Kuhn, Väderstad, Manitou, Lemken, Kongskilde, Joskin and Hardi, as well as machines produced by Polish enterprises which together form Unia Group. The maintenance services of agricultural vehicles and machines performed by the servicing department in company garages $(r=0)$ and the works conducted by mechanic teams on farms and under field conditions $(r>0)$ were ordered in the form of monthly observations. The statistical analysis of maintenance services of agricultural vehicles and machines was conducted with the use of the R programme (Aczel and Sounderpandian 2009, Crawley 2013).

\section{RESEARCH RESULTS}

During 11 years of research, servicing centres realised in total 17,402 orders in company garages, on farms and under field conditions. The distribution of maintenance services on a monthly basis is presented in a histogram (Fig. 1).

The research into the structure of the territorial configuration of service orders confirmed:

- 10,616 service orders with $\mathrm{r}=0 \mathrm{~km}$,

- 1,297 service orders with $0 \mathrm{~km}<\mathrm{r} \leq 50 \mathrm{~km}$,

- 1,687 service orders with $50 \mathrm{~km}<\mathrm{r} \leq 100 \mathrm{~km}$,

- 3,802 service orders with $r>100 \mathrm{~km}$. 


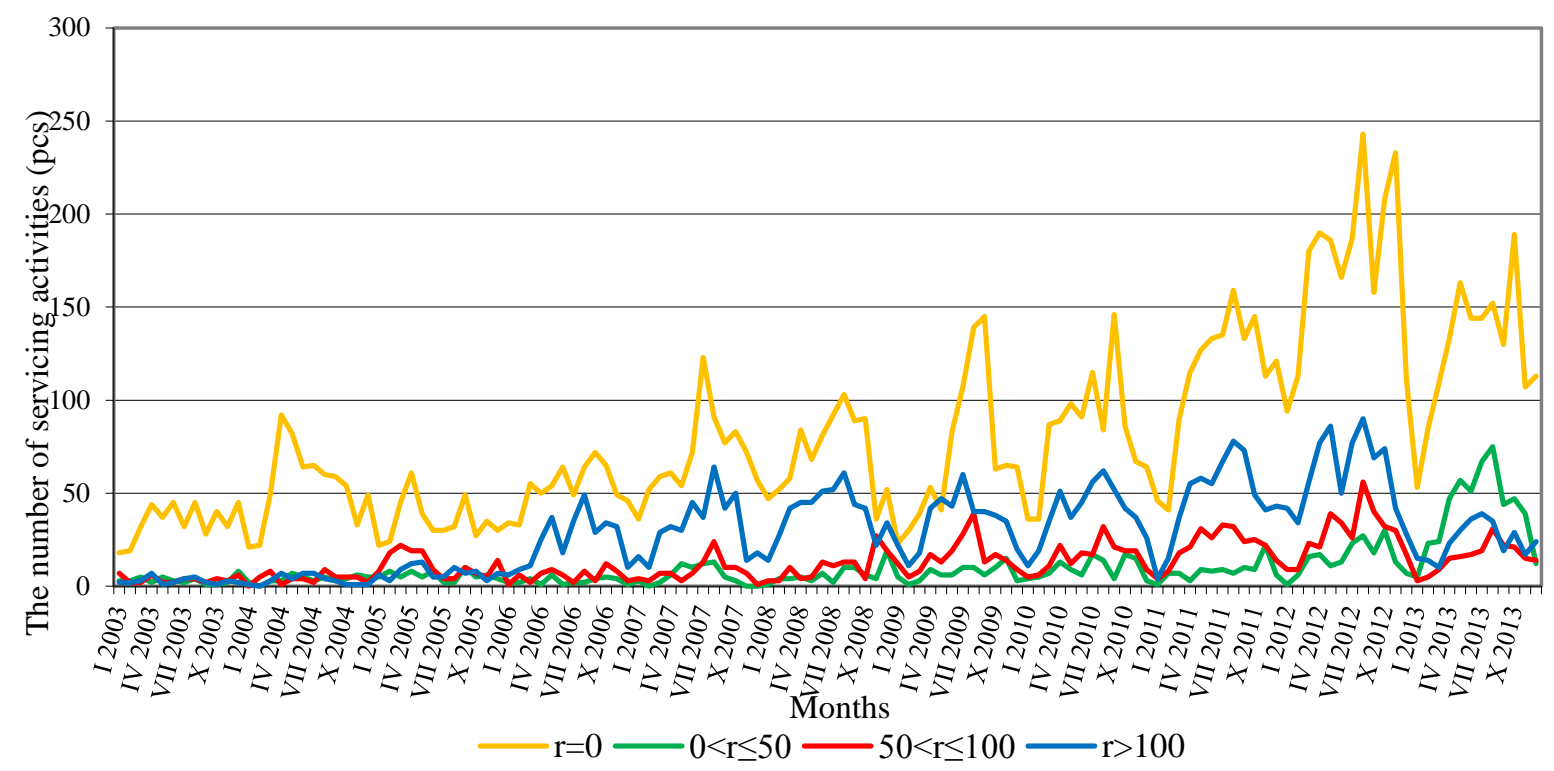

Fig. 1. The distribution of the number of inspections and repairs of farm vehicles and machines carried out by the service point for particular radiuses of distance in the years 2003-2013 (The author's own study)

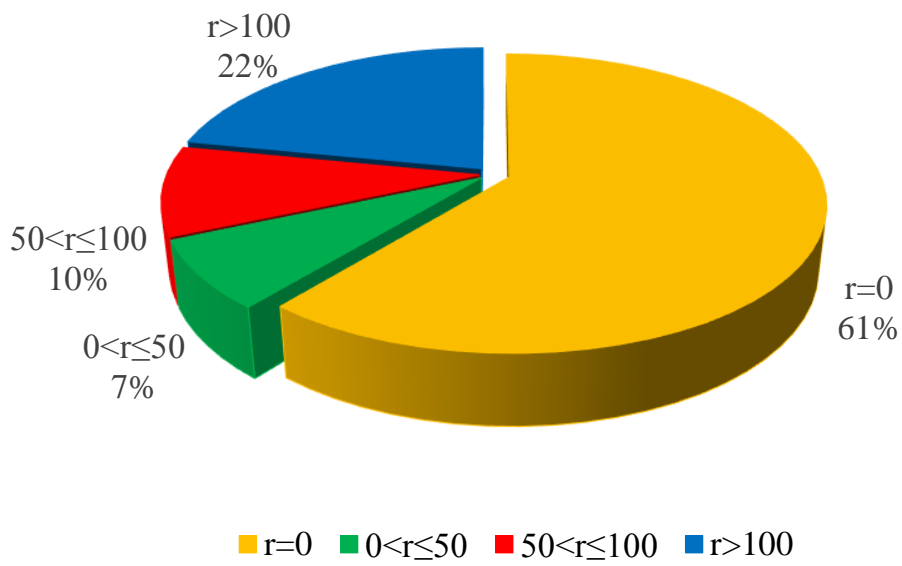

Fig. 2. The structure of the number of inspections and repairs of farm vehicles and machines carried out by the service point in the years 2003-2013 (The author's own study)

The structure of the number of inspections and repairs of agricultural vehicles and machines conducted by service stations attests to a large representation (39\%) of orders executed in the field. It constitutes a significant condition for reducing the time necessary for executing the order, and thus reduces the costs of business activities (Fig. 2). Optimisation of time and costs is particularly important in the aspect of sustainable system of farming.

\section{DISCUSSION}

The value of seasonal indices for maintenance services of agricultural vehicles and machines conducted at the premises of the company's service station is presented in Fig. 3. 


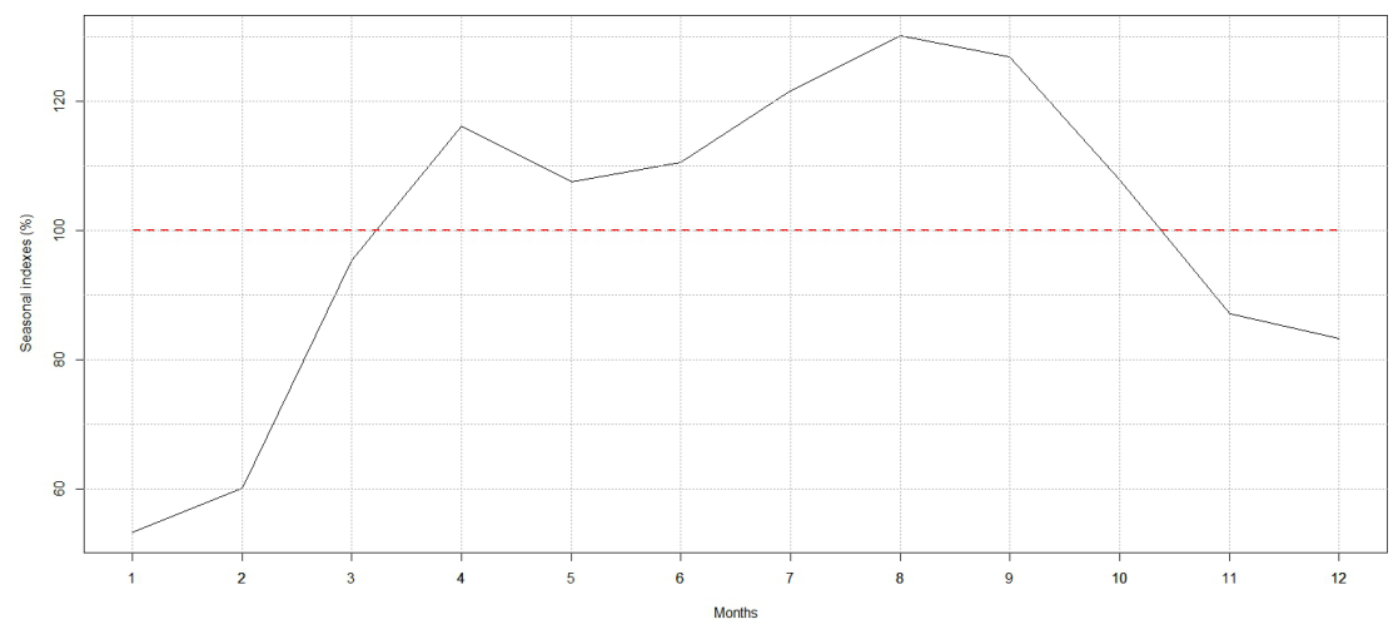

Fig. 3. Seasonal indices for the number of inspections and repairs of farm vehicles and machines for radius of distance $\mathrm{r}=0$ in the years 2003-2010 (The author's own study)

In the first quarter of the year, the number of works performed by the service station was less than the reference level by, respectively, $45.14 \%, 39.14 \%$ and $4.0 \%$. The period when no agrotechnical practices are carried out and therefore there is a reduction in the use of vehicles and machines was characterised by decreased demand for their servicing. As a result of seasonal variations, after the beginning of spring agricultural works, an increase in the number of service orders was noted, with their value higher than the average level by $19.42 \%$ in April. In subsequent months, seasonal demand for maintenance services was gradually increasing. The harvest of cereals and root crops from July to September resulted in a maximum increase in demand, with indices reaching the values of, respectively, $21.8 \%, 32.3 \%$ and $27.8 \%$ above the reference level. As a result of seasonal variations, after agricultural works were finished, there was a decrease in the number of orders, and seasonal indices were lower by respectively $19.5 \%$ and $13.4 \%$ than the average level.

The value of seasonal indices for maintenance services of agricultural vehicles and machines conducted on farms and under field conditions ( $r>0)$ is presented in Fig. 4.

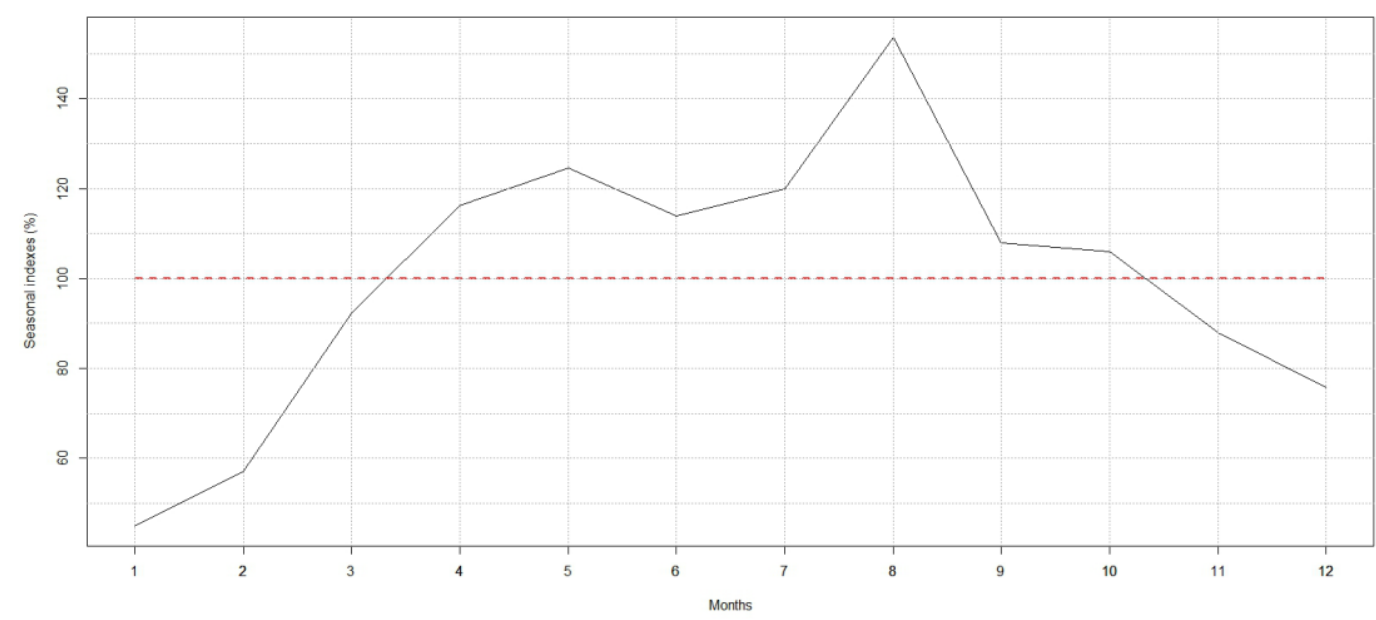

Fig. 4. Seasonal indices for the number of inspections and repairs of farm vehicles and machines for radius of distance $r>0$ in the years 2003-2010 (The author's own study) 
In January, February and March, the number of services performed by servicing teams was lower than the reference level by, respectively, 55.1\%, $42.9 \%$ and $7.8 \%$. Seasonal variations resulted in a radical decrease in demand for maintenance services conducted in the field during the winter period, as in general, weather conditions in Poland make it impossible to perform such tasks. The period of spring agricultural works brought about an increase in the number of orders for inspections and repairs executed by servicing teams. From April to July, seasonal indices were higher than the reference level by, respectively, $16.3 \%, 24.5 \%, 14 \%$ and $20 \%$. The period of cereal harvest in August marks the seasonal maximum demand for maintenance services conducted in the field. It was then that index reached the value of $53.7 \%$ above the reference level. In September and October, during root crops harvest and autumn agricultural works, seasonal indices were slightly above the reference level. After the end of agricultural works, a seasonal decrease in the number of orders was noted, and seasonal indices in November and December amounted to, respectively, $12.1 \%$ and $24.3 \%$ below the average level.

\section{CONCLUSIONS}

1. Demand for servicing of agricultural vehicles and machines carried out in service stations $(r=0 \mathrm{~km})$ as well as on farms and under field conditions $(0 \mathrm{~km}<r \leq 50 \mathrm{~km}, 50 \mathrm{~km}<r \leq$ $100 \mathrm{~km}$ and $r>100 \mathrm{~km}$ ) varied over the period of the research. The number of inspections and repairs carried out increased during the majority of the studied periods. The creation of a large population of vehicles and machines in the area served by a dealer dynamised the increase in the number of conducted maintenance services.

2. The structure of the obtained values of seasonal indices constitutes a basis for concluding that agrotechnical works and practices considerably affect cyclical changes in demand for servicing agricultural vehicles and machines. As a result of seasonal variations, there was a radical reduction in demand for servicing during the winter months, when no agricultural works are carried out. Seasonal variations, in turn, caused an increase in demand for servicing in the spring and during cereal harvest and autumn agricultural works.

3. Services carried out in the field $(r>0 \mathrm{~km})$ provide important support for agricultural production, and in terms of sustainable agriculture, they optimise its efficiency. Activities of servicing teams in the field constitute a serious organisational and logistic challenge, which needs to undergo ongoing verification in order to optimise mechanics' time of work and to reduce distances they travel to customers.

\section{REFERENCES}

Aczel A. D., Sounderpandian J. (2009). Complete Business Statistics, 7th ed., R.D. Irwin/McGraw-Hill, Boston.

Buchwald T., Staszak Ż. (2013). Comparative analysis of the selected processes of the technical service of agricultural machines. Agricultural Engineering 3(145), 9-16.

Crawley M.J. (2013). The R book. Chichester: J. Wiley \& Sons Ltd. $2^{\text {nd }}$ ed., pp.1051

Cupiał, M., Kobuszewski, M. (2011). Optimisation of technical infrastructure of the selected farms with the use of OTR-7 programme. Agricultural Engineering, 8(133), 69-74.

Cupiał M, Szeląg-Sikora A., Niemiecb M. (2015). Optimisation of the machinery park with the use of OTR-7 software in context of sustainable agriculture, DOI: 10.1016/j.aaspro.2015.12.034, Agriculture and Agricultural Science Procedia 7, $64-69$.

Gazzarin, Ch. (2014). Maschinenkosten 2014. Technik Agroscope Transfer, 37, 52

Gazzarin, Ch., Lips, M. (2013). Berechnung und Grunddaten der Maschinenkosten. Maschinenkostenbericht, Juni, pp.33

Juściński S. (2012a). The analysis of distribution logistics of new farm machines in the context of changes in the demand structure. Journal of Research and Applications in Agricultural Engineering, 57(2), 85-91. 
Juściński, S. (2012b). An analysis of the new tractors distribution logistics in the aspect of the European Union programmes for supporting agriculture modernization. Journal of Central European Agriculture, 13 (4), 850868.

Juściński S. (2012c). The analysis of demand for technical maintenance services of farm vehicles and machines in the context of the distance from the service point, Annales Universitatis Mariae Curie-Skłodowska Sectio E Agricultura, Vol. LXVII(3), 74-90.

Lorencowicz E., Cupiał M. (2013). Ocena aktywności inwestycyjnej rolników wykorzystujących fundusze unijne na przykładzie województwa lubelskiego, Acta Scientarium Polonorum, Oeconomia, 12 ( 1 ), 17 - 26

Lorencowicz, E., Cupiał, M. (2012). Wpływ dotacji unijnych na koszty eksploatacji maszyn rolniczych, Roczniki Stowarzyszenie Ekonomistów Rolnictwa i Agrobiznesu, t XIV, z.7, 81-86.

Niari, S.M., Ranjbar, I., Rashidi, M. (2012). Prediction of Repair and Maintenance Costs of John Deere 4955 Tractors in Ardabil Province, Iran. World Applied Sciences Journal, 19 (10), 1412-1416

Rzeźnik C., Durczak K., Rybacki P. (2015). Serwis techniczny maszyn, Wydawnictwo UP w Poznaniu. ISBN 978-83-7160-788-2.

Skrobacki A., Ekielski A. (2012). Pojazdy i ciągniki rolnicze, Wyd. Wieś Jutra, Warszawa.

Tomczyk, W. (2015). Assessment of the repair infrastructure efficiency with regard to maintenance of farm machines. Agricultural Engineering, 3(155), 131-138. 